\title{
Stress field analysis and its effect on selection of optimal well trajectory in directional drilling (case study: southwest of Iran)
}

\author{
Mohammad Abdideh $^{1} \cdot$ Fawzi Dastyaft ${ }^{1}$
}

Received: 21 May 2021 / Accepted: 13 October 2021 / Published online: 28 October 2021

(c) The Author(s) 2021

\begin{abstract}
Given the complexities of reservoir exploration and development, it is vital to understand the geomechanical properties of the reservoir and well in the drilling operation. In constructing a mechanical model of the earth, a combination of environmental geomechanical parameters, as well as the magnitude and direction of stresses, is used. In this study, stress analysis and its effect on azimuth well in deviated drilling in an oil field located in southwestern Iran are investigated. Necessary geomechanical parameters are estimated using density and slowness logs of sonic waves (shear and compression). The Mohr-Coulomb failure criterion is followed to determine a safe mud weight window. A mechanical model of the earth is designed using laboratory data and well logging, and it is validated by the results obtained from laboratory rock mechanics using the calibrated core samples. The results show that drilling in the azimuth at about $135^{\circ}$ with an angle of about $15^{\circ}$ is the most stable path for the well in the carbonate reservoir formation in the studied oil field.
\end{abstract}

Keywords Geomechanics $\cdot$ Petrophysics $\cdot$ Stress field $\cdot$ Safe mud window $\cdot$ Directional drilling $\cdot$ Optimal well trajectory

\section{Introduction}

Rock mechanics, as a sub-branch of geomechanics, uses the concepts of continuity, solid mechanics, and geology to determine the behavior of rock environments against environmental stresses. In petroleum geomechanics, a prediction of rock behavior, compaction, failure, and fault in oil and gas reservoirs due to exploitation drilling is investigated. Although almost a century has passed since the beginning of the exploration drilling industry, the science of geomechanics has recently entered the industry.

The importance of drilling planning and operation of hydrocarbon reservoirs is becoming increasingly apparent due to the decline in oil prices and competitive production of hydrocarbon resources. One of the problems occurring in most drilling wells is the instability of the wellbore, which leads to sticking pipes to the well, decreasing well diameter, losing mud, increasing well diameter, and flowing well. In some cases, the costs are increased by up to 1 billion $\$$ a year (Al-Ajmi 2006). The stability of the wellbore is not only

Mohammad Abdideh

m.abdideh@yahoo.com

1 Department of Petroleum Engineering, Omidiyeh Branch, Islamic Azad University, Omidiyeh, Iran influenced by drilling but also by reducing pore pressure during the operation in the fields.

Instability of wellbore can occur at various stages of a well's life, including drilling, completion, as well as flow and production tests (Fjar 2008). These instabilities are the main source of drilling problems, leading to high cost and time waste and sometimes loss of the entire well (Zoback 2010). Oil companies spend a lot of time and money dealing with the problems caused by the wellbore instability in drilling operations. There are various opinions about the cost due to the instability of the wellbore, which is estimated to be about $\$ 1$ billion per year (Zeynali 2012). Therefore, it seems necessary to investigate this issue in order to reduce such costs.

Many parameters influence the instability of the wellbore. Some of these parameters are related to the properties of drilling mud and its interaction with formation, and some are related to mechanical properties of formation and the amount of stress direction around the well. In general, the instability of wellbore can be related to physicochemical and mechanical factors or their combination (Maleki 2014).

It is necessary to build a geomechanical model to predict the safe and stable weight range of drilling mud windows in future wells and better understand the parameters influencing the wellbore instability (Kidambi and Kumar 2016). 
Geomechanical model is a logical set including information related to geology, regional stresses, rocks' mechanical properties, and pore pressure; it is used to quickly update information used in drilling operation and reservoir management (Moos 2003).

The wellbore instability is predicted using failure criteria and models that calculate the stresses around the well. Failure criteria used in stability analysis include Mohr-Coulomb, Drucker-Prager, Mogi-Coulomb, modified lead, and three-dimensional Hoek-Brown models.

Each of these failure criteria predicts different values for rock strength and minimum mud weight required for wellbore stability; therefore, choosing failure criterion is difficult and controversial for analysis of wellbore stability (Amiri et al. 2019).

Many researchers have studied the application of geomechanics to analyze wellbore stability, some of which are introduced below.

Al-Ajmi presented the Mogi-Coulomb criterion to analyze shear failures in rocks (2006). Due to the ability of this criterion to model failure in rocks, in 2009, a model of vertical, directional, and horizontal wellbore stability was presented (Ameen et al. 2009).

Poisson's ratio and Young's modulus could be predicted through vertical seismic profiles determining shear and compression wave velocity and using some experimental equations (Rutqvist et al. 2009). Also, Ameen et al. investigated the relationship between porosity and elastic parameters of rock and could provide elastic logs of rock based on empirical relationships (2009).

Zhang et al. performed five failure measurement experiments on five different rock samples and showed the best failure criteria for wellbore stability analysis to be the threedimensional Hoek-Brown and Mogi-Coulomb criteria based on the evaluated samples (2010).

Younesi and Rasouli also studied the effect of landslides along fractures on the wellbore stability and provided an index to investigate landslide potential. They showed that using the presented method, the instability of wellbore could be investigated based on the reactivation mechanism of faults and fractures (2010).

In addition, Rajabi et al. used well logs to determine the velocity of compression and shear waves (2010).

Mirzaghorbanali and Afshar determined mud weight window based on the Mogi-Coulomb refractive index and elastoplastic model (2011). They showed that such models offer better results than those conventional ones. Maleki (2014), at an oil field near Khark Island, applied the three Mohr-Coulomb, Mogi-Coulomb, and Hoek-Brown failure criteria in analyzing the wellbore stability. According to the studied environment (Burgan sandstone reservoir), the Mogi-Coulomb failure criterion provided more accurate results (Maleki 2014). In the same year, Gholami et al. used the Mohr-Coulomb, Hoek-Brown, and Mogi-Coulomb failure criteria to determine safe window and mud weight for drilling one well in the Khuzestan Oil Field in Iran (2014). They showed that the wellbore stability analysis using the Mogi-Coulomb failure criterion was in better agreement with diametric diagram data.

Shen et al. presented a flowchart for one-dimensional analysis of pore pressure and safe mud window estimates in high-angle wells (Shen et al. 2015). Also, Ma et al., in collaboration with the just mentioned team, analyzed stability and optimization of the well path based on the Mogi-Coulomb failure criterion and the breakout width model. It was concluded that this hybrid model could produce the lowest amount of safe mud window in agreement with its actual amount (Ma et al. 2015).

The mechanical earth model (MEM) represents mechanical stress, pore pressure, and properties of a particular section in a field or basin. This model includes all geomechanical information to analyze any geomechanical applications, including wellbore stability analyzing, sand production forecasting, hydraulic fracture reservoir designing, compacting, and reservoir subsiding. The best necessary method can be achieved for drilling operations and safe completion in a well and the well field by constructing a geomechanical model (Amiri et al. 2018).

The ultimate goal of this study was to develop a onedimensional geomechanical model in the well APP2 in one of the oil fields in southern Iran. Accordingly, core samples and interpretation of various logs were used in modeling. Rock mechanics tests were performed on core samples taken from the well. The tests were as follows:

Uniaxial compression resistance test uses the ASTMC170 ISRM and ASTM-D2938 standards, the results of which were analyzed and processed to construct a geomechanical model.

In this research, petrophysical logs were used along with the calibrated core mechanical results obtained from the laboratory to construct a geomechanical model and perform wellbore stability analysis.

\section{Geological setting}

The studied oil field is located in Khuzestan Province and Abadan Plain (southwest of Iran). Its length is $20 \mathrm{~km}$ and its width is $2.5 \mathrm{~km}$, in the N-S direction with an approximate area of 52 square kilometers. In other words, this field is located along the Iranian-Iraqi border.

Based on the available information from the wells, the four main production horizons in this field include Sarvak, Kajdomi sandstone, Gadvan, and limestone layers in Fahliyan Formation. It should be noted that there are no 
geological outcrops in this field at ground level, and the obtained information is based on the results of the 3D seismic method.

The formations and lithological characteristics of this oil field are presented in Table 1.

\section{Materials and methods}

In general, the instability of the wellbore is classified into the following two categories:

(A) Chemical origin instability: The most common instability of chemical origin is related to water absorption by shale formations and leaching of salt formations by the aqueous phase of drilling fluid. Absorption of water in shale causes swelling and loss of formation, leading to more or less well diameter. Leaching of salt formations may cause large cavities around the wellbore, or it may contaminate drilling fluid. This type of instability can be counteracted by changing the chemical composition of the drilling fluid (Gao 2019).

(B) Mechanical origin instability: Before drilling, rocks of the formation are less than the strength of the rock, and chemical conditions in the formation are in equilibrium. With the start of drilling, load on the rocks around the well is removed, and the stresses left around the well are increased, showing stress concentration. Depending on the strength of the rock, stress concentration can cause the wellbore to break. Mechanical stability manages the stresses preventing shear and tensile failure in the rock. Typically, these stresses are compact and create shear stresses in the rock. The more closely these stresses (equal to each other), the more stable the rocks are (Zoback 2003).

The MEM is actually a numerical representation of the geomechanical information available for a field or basin. Planning for drilling high-risk wells without using a MEM can dramatically increase the costs. For example, in the absence of a MEM and the presence of the wellbore instability, it is not possible to correctly decide whether to reduce or increase the weight of drilling mud.

\section{- One-dimensional MEM}

A one-dimensional MEM includes all geomechanical parameters against depth. In this model, drilling data against depth can also be provided. Geomechanical parameters involved in the one-dimensional mechanical model of stratigraphy referred to as hard data are as follows (Lund and Zoback 1999):
- Poisson's ratio

- Young's modulus

- Uniaxial compressive strength

- Friction angle

- Pore pressure

- Minimum horizontal stress

- Maximum horizontal stress

- Vertical stress

- Horizontal stresses direction

The above data are used to determine the safe mud window (the amount of mud weight if used, minimizing the number of tensile and shear failures).

\section{- Three-dimensional MEM}

In this model, the two-dimensional plates of fracture, fault, and head of formations are interpreted according to seismic data; they are used together with well log data.

\section{Estimation of safe mud window}

Instability of wellbore occurs due to rock failure from two main types of tensile and shear failure. Shear failure usually occurs due to low mud weight, and tensile failure occurs due to high mud weight. There are several methods to predict rock failure and instability of wellbore, such as using failure criteria.

Safe mud window is one of the outputs regarding analysis of wellbore stability, the concept of which is shown in Fig. 1. In defining a safe mud window, four points are essential:

\section{- Pore pressure}

If the amount of mud weight and, consequently, the pressure inside the well is less than pore pressure, one can expect a washout and well flow. Of course, it should be noted that the swabbing process, causing a sudden decrease in the pressure inside the well to the extent less than the formation pressure, can have a similar effect. (In the pipe-raising operation, separation of the drill from bottom of the well reduces the pressure inside. This phenomenon is called swab.)

- The minimum amount of mud weight to prevent breakout failure

At mud weight less than safe mud weight, the rock breaks, and the lower the mud weight, the more severe the breakout fracture; the swabbing process can have a similar effect (Kanfar et al. 2017).

- The minimum main stress level (herein, the minimum horizontal stress) 
Table 1 Underground formations with their lithological characteristics in the studied oil field

\begin{tabular}{|c|c|c|}
\hline Formation & Column & Lithology description \\
\hline Aghajari & $\because ニ=L 亡=\perp=1$ & Marl, sand-shale \\
\hline & 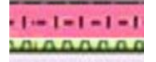 & Anhydrite sandstone Limestone dolomite with hioh-pressure salt aguifer Salt bed salt water $115 \mathrm{SG}$ \\
\hline Gachsaran & manmminn & Anhydrite, sandstone, Limestone, dolomite with high-pressure salt aquifer. Salt bed, salt water 1.15SG \\
\hline Asmari & 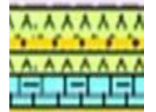 & Sandstone, sandy limestone, limestone, dolomite with salt aquifer, $\mathrm{H}_{2} \mathrm{~S}$. Salt water $1.15 \mathrm{SG}$ \\
\hline Pabdeh & $\frac{1}{F}$ & Limestone, shale and silt interbed, interbedded horizons glauconite, with salt aquifer, $\mathrm{H}_{2} \mathrm{~S}$. Salt water $1.15 \mathrm{SG}$ \\
\hline Gurpi & & Argillaceous limestone and marl with scattered glauconite, asphalt, with salt aquifer. Salt water 1.15SG \\
\hline Ilam & & Limestone, argillaceous limestone, shale interbed. Salt water $1.15 \mathrm{SG}$ \\
\hline Lafan & & Shale and dolomite \\
\hline Sarvak & & $\begin{array}{l}\text { Limestone to argillaceous limestone, in the lower part is shale and dolomite, with salt aquifer. Salt water } \\
1.15 \mathrm{SG} . \mathrm{H}_{2} \mathrm{~S}\end{array}$ \\
\hline Kazhadumi & & Argillaceous limestone and sand in lower part. Salt water $1.15 \mathrm{SG}$ \\
\hline Dariyan & & Limestone with salt aquifer \\
\hline Gadvan & & Limestone to sandstone, shale and silt shale, with salt aquifer. $\mathrm{H}_{2} \mathrm{~S}$. Salt water $1.15 \mathrm{SG}$ \\
\hline Fahilyan & & Limestone to sandy limestone. Salt water $1.15 \mathrm{SG}$ \\
\hline
\end{tabular}

If there are natural fractures or any other conductive properties around the wellbore or in the high permeability zone, then mud weight pressure more than the original stress is expected to open the natural fractures and cause loss of the drilling mud. In formations with high fractures, any pressure greater than horizontal stress can at least cause geometric fractures, propagating them toward the wellbore. Excessive mud or surge in the pipe-lowering operation can have similar effects. (In this operation, the pressure of the drill bit on the mud in the well increases the pressure inside the well, called the surge phenomenon.)

\section{- Formation of fracture pressure}

When the failure pressure of the mud is higher than that of the formation, it leads to developing tensile failures. Tensile failures are also called hydraulic and inductive failures. If the rate of failure pressure exceeds the original minimum stress (here, the minimum horizontal stress), loss of circulation will occur.
In general, it can be said that the ideal mud weight should be more than the pore pressure. The minimum mud weight to prevent breakout should be less than the horizontal stress and failure pressure of the formation, as shown in Fig. 1.

In this study, the information of in-well logs of sonic (DT), gamma ray (GR), neutron porosity (NPHI), bulk density (RHOB), and caliper (CAL) from the depth of 19304263 was used to estimate elastic properties of the rock (elastic deformation and strength parameters) in the APP2 well after revision (Fig. 2). Overall, different types of data, such as in-well tests, drilling data, in-well logs, and rock mechanics tests, were used in the study.

In this research, Techlog software, as one of the unique software applications in the world used in petroleum engineering, was applied. It has various analyses; definite and non-definite petrophysical analyses; image log analysis, texture analysis, dip log analysis, and core analysis (included in geology section); the analysis of wellbore stability, estimation of overburden stress, and study of fracture gradient (included in drilling section); the analysis of hydrostatic pressure, analysis of pressure gradient, and PC modeling 
Fig. 1 Safe mud weight window

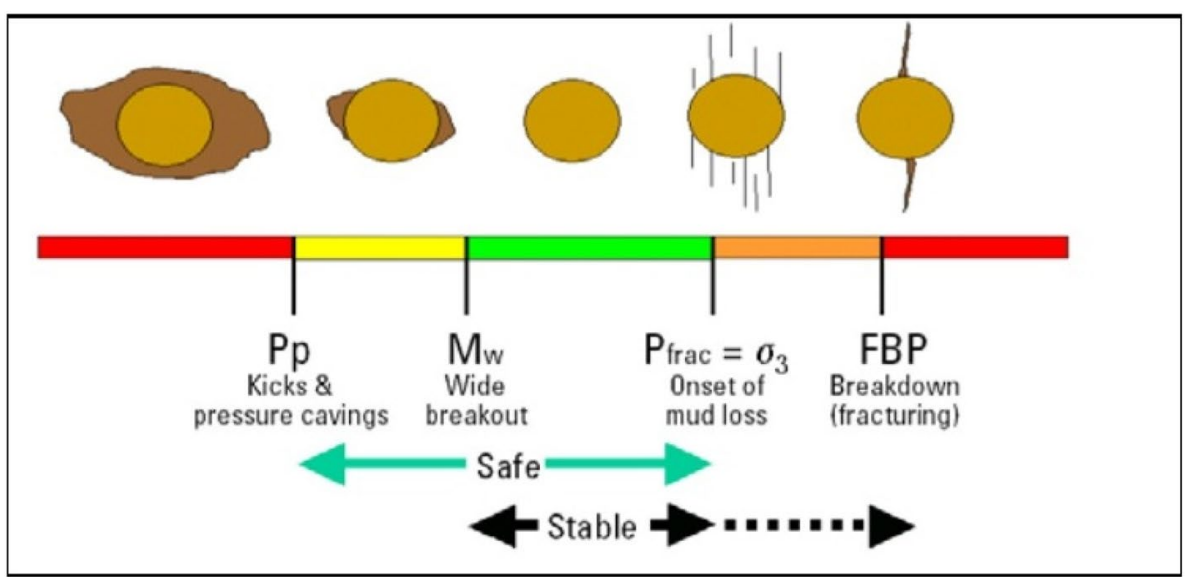

(included in pressure engineering section); time-to-depth conversion, quality control (QC) plots, Delta-T processing, and reservoir that are unconventional (included in geophysics section).

\section{Results and discussion}

The well stability model in the studied oil field was based on geological information, in-well log information, rock mechanics laboratory data, as well as drilling and reservoir experiments.

In this study, the data obtained from the image log (FMI) were used to determine the direction of the main stresses in the region. These stresses were also calibrated using the wells' leak-off test (LOT) information.

\section{Construction of geomechanical model (MEM) and its calibration}

Various steps are performed to construct a geomechanical model for one- or two-dimensional geomechanical analysis in a well or three-dimensional analysis in an oil field. Figure 3 shows a general flowchart of the steps for constructing a geomechanical model using in-well data and logs.

Uniaxial compressive strength (UCS) is the most common criterion in calculating the rocks' strength. This parameter is the primary criterion in estimating the stability of the wellbore due to the formation failure pressure.

In this study, multistage triaxial compressive tests performed on core components were used to calibrate UCS calculated from in-well logs.

Determining the formation tensile strength is vital to evaluate the tensile strength caused by stress concentration in the wellbore. This parameter was obtained from the results of the Brazilian test. Table 2 provides the values obtained in the Brazilian and uniaxial tests for the studied well. Based on this, a graph sequence was obtained for the values of static
Young's modulus, uniaxial strength, and tensile strength along the well (Fig. 4).

Figure 5 shows the elastic parameters calculated in the well. As shown, a good agreement was observed between the static Young's modulus calculated from the in-well logs and that calculated in the laboratory tests, indicating the validity of the calculated elastic properties. This finding was also true for Poisson's ratio.

The internal coefficient of friction $(\mu)$ and cohesion (C) along the well path were both calculated using a sonic $\log$ (DT) (Fig. 6). Also, a good correlation was observed between the rocks' strength calculated from the in-well logs and core data, indicating a suitable calibration in the design of the geomechanical model.

\section{Magnitude of in situ stresses}

Normally, one of the main stresses is vertical, and the other two stresses are horizontal. Vertical stress is obtained through the following equation. Of the two horizontal stresses, the minimum horizontal stress $\left(\sigma_{h}\right)$ is obtained indirectly using the mini-fracture test with a reasonable estimate.

$\sigma_{v}=\int_{0}^{z} \rho_{b}(z) \cdot g \mathrm{~d} z$

Irrespective of temperature, the minimum and maximum horizontal stress values can be achieved using the following prolastic relations:

$$
\begin{aligned}
& \sigma_{h}=\frac{v}{1-v} \sigma_{v}-\frac{v}{1-v} P_{p}+\frac{E}{1-v^{2}} \varepsilon_{x}+\frac{v E}{1-v^{2}} \varepsilon_{y} \\
& \sigma_{H}=\frac{v}{1-v} \sigma_{v}-\frac{v}{1-v} P_{p}+\alpha P_{p}+\frac{E}{1-v^{2}} \varepsilon_{x}+\frac{v E}{1-v^{2}} \varepsilon_{y}
\end{aligned}
$$




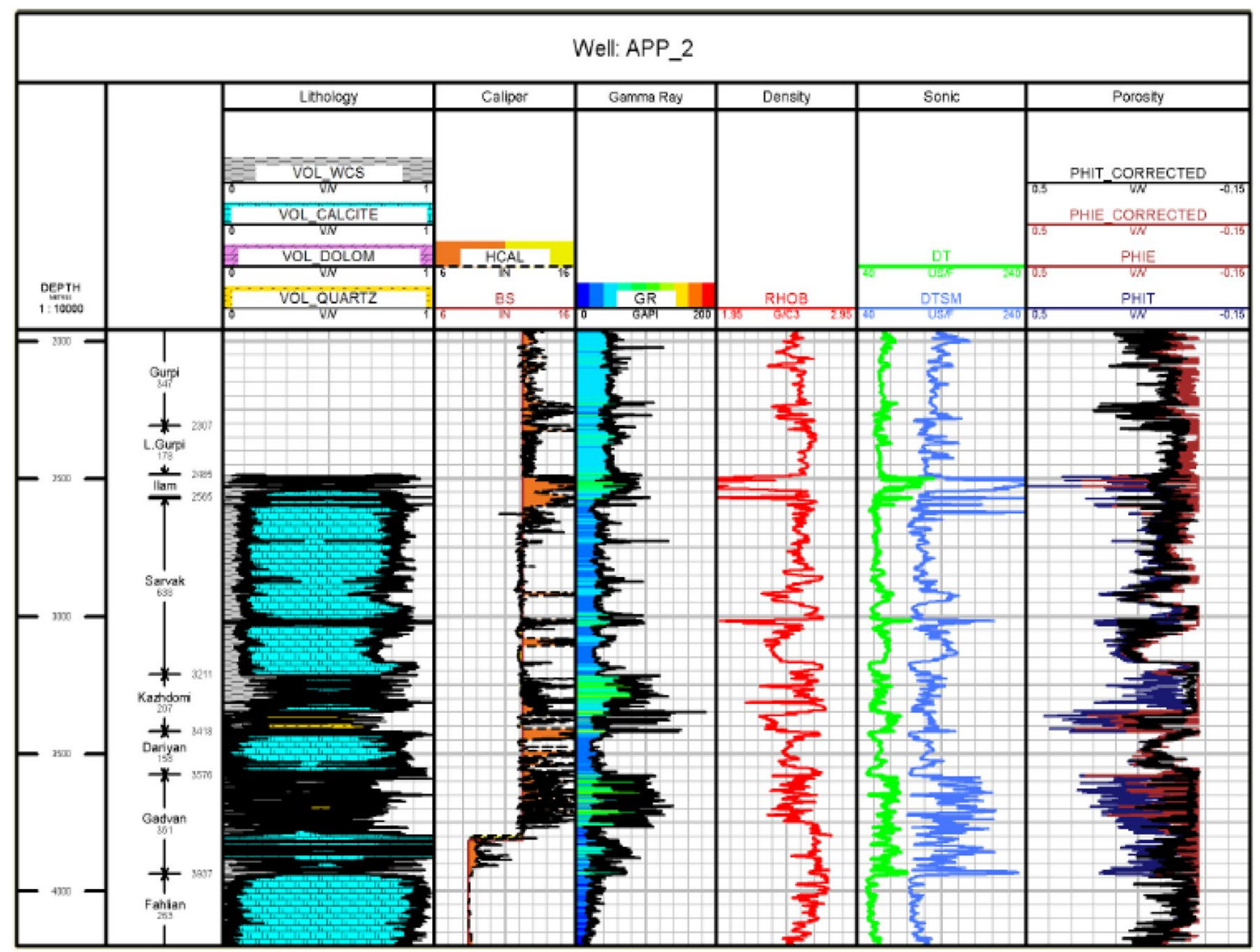

Fig. 2 Log data of the APP2 well

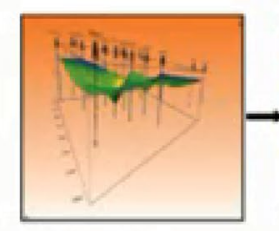

Data Audit

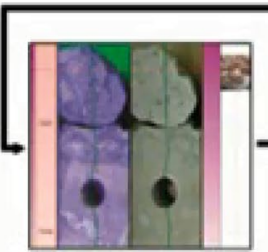

Mechanical

Properties

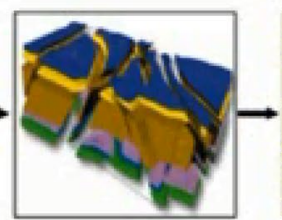

Framework

Model

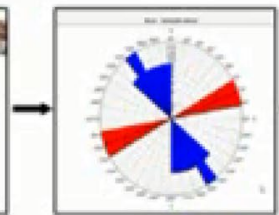

Stress

Direction

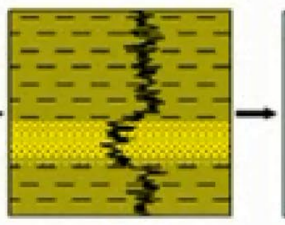

Mechanical

Stratigraphy

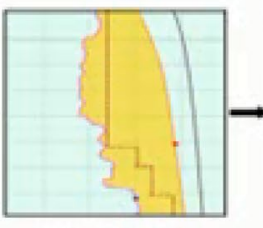

Overburden

Stress
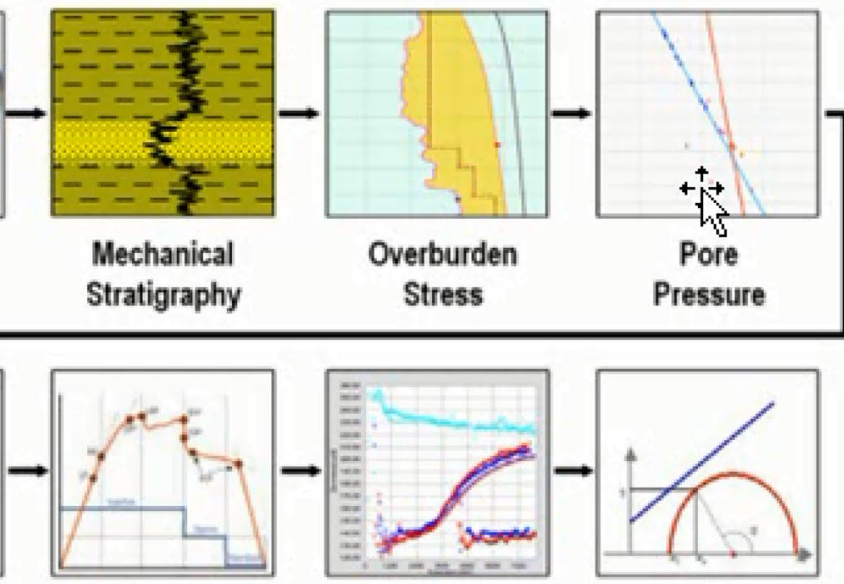

Minimum

Stress

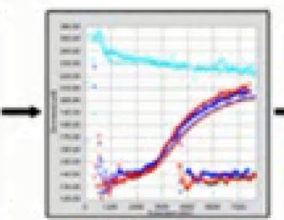

Maximum

Stress

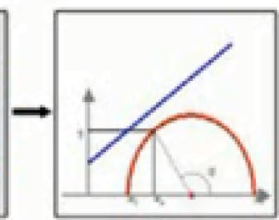

Failure

Analysis

Fig. 3 Flowchart of the steps to construct a geomechanical model 
Table 2 Rocks' strength parameters obtained from Brazilian laboratory and triaxial tests

\begin{tabular}{lllll}
\hline Depth $(\mathrm{m})$ & Poisson's ratio & $\begin{array}{l}\text { Young's } \\
\text { modulus } \\
(\mathrm{GPa})\end{array}$ & $T(\mathrm{MPa})$ & UCS (MPa) \\
\hline 2488.7 & 0.14 & 9 & 2.7 & 16 \\
2600.28 & 0.22 & 11 & 1.3 & 20 \\
2619.54 & 0.1 & 8 & 2.6 & 14 \\
2666.8 & 0.22 & 8 & 2.7 & 27 \\
2687.53 & 0.17 & 23 & 4.3 & 54 \\
3972.39 & 0.1 & 21 & 2.2 & 63 \\
4014.53 & 0.2 & 20 & 5.4 & 40 \\
\hline
\end{tabular}

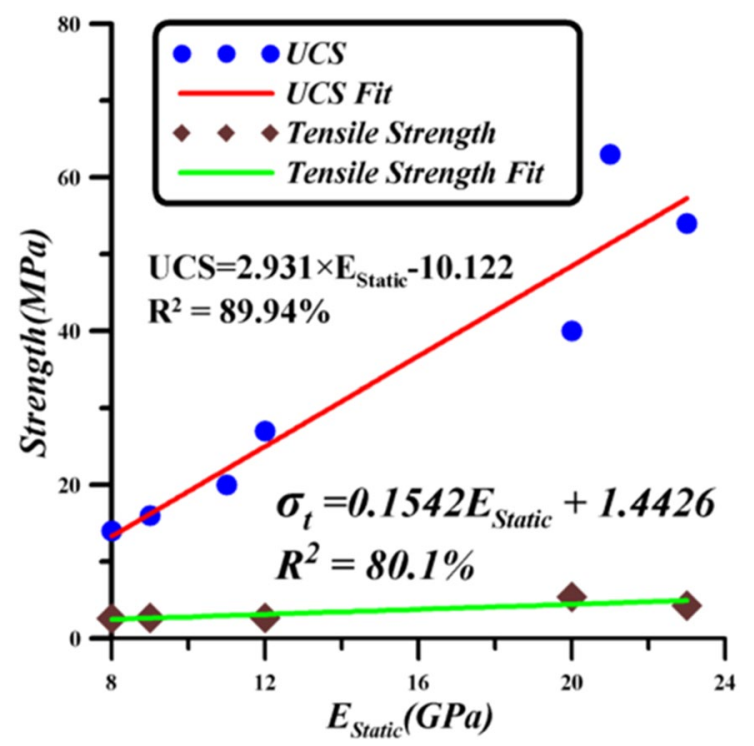

Fig. 4 Interpolation of uniaxial and tensile strength values with static Young's modulus in the studied well

where $\sigma_{v}, \sigma_{h}, P_{p}$, and $\sigma_{H}$ are the vertical-horizontal minimum stresses, pore pressure, and maximum horizontal stresses in meg pascal, respectively; Young's modulus is in Giga pascal, and $\alpha$ is the Biot's coefficient.

The values $\varepsilon_{\mathrm{x}}$ and $\varepsilon_{\mathrm{y}}$ are horizontal strains in the region that can be compressive or tensile depending on the region's tectonics. These values are calibrated using the LOT data in the well. Due to the lack of information on the rock particles, bulk modulus which is used to calculate the Biot's coefficient is considered equal to 0.7 along the well, a common value in carbonate lithology (Abdollahipour 2015).

Joint opening (pressure drop in LOT) occurs when the inlet pressure reaches a critical level called the formation failure pressure. In this case, the tangential stress around the well $\left(\sigma_{\theta \max }\right)$ equals tensile stress $\left(\sigma_{t}\right)$.

$\sigma_{\theta \max }=-\sigma_{t}$
The maximum horizontal stress value is calculated as follows by placing the above equation in the hydraulic failure equations:

$\sigma_{H}=3 \sigma_{h}-\mathrm{FBP}+\sigma_{t}$

The maximum stress obtained from the above relation is applied only to non-porous rocks, thus for those without pore pressure. Given the pore pressure of the formation, the above relation is written as follows:

$\sigma_{H}=3 \sigma_{h}-\mathrm{FBP}+\sigma_{t}-P_{p}$

Figure 7 shows the LOT and formation breakdown pressure (FBP) values obtained from the diagram. The LOT value is equal to the main stress, at least around the well. Thus,

$\sigma_{h}=\mathrm{LOT}=2080+3818=5898 \mathrm{psi}=40.66 \mathrm{Mpa}$

It should be noted that the pressure shown in Fig. 7 is the one at the end of the well. In order to calculate the total pressure, the pressure from the drilling mud column must be added to the above value. The input parameters for calculating the horizontal stress at a maximum depth of $2205 \mathrm{~m}$ are given in Table 3 .

The maximum horizontal stress value at this depth was calculated as $57.19 \mathrm{MPa}$ by placing the information in Table 3 in the above equation.

This calculation is used to calibrate the prolastic stress equations; the values of $\varepsilon_{x}$ and $\varepsilon_{y}$ were calculated as 0.9635 and 2.7091 , respectively, by placing the main stresses obtained in the prolastic relations; therefore, the values of the main stresses are calibrated by these values.

The square symbol in the stress column in Fig. 8 represents the maximum horizontal stress value in calibrating the maximum horizontal stress graph, and the circle symbol represents the minimum horizontal stress value obtained from LOT to calibrate the maximum horizontal stress graph. According to the stress diagram in Fig. 8, the stress regime is defined in a normal and strike-slip zone. In the lower parts of the well, as well as in the Gadvan Formation and many parts of the Fahliyan Formation, the stress regime becomes normal. In the following, information is presented regarding how the outcome of the main stresses and mud column pressure determines the stability of the wellbore using parameters derived from the data of drilling reports and changes in the well radius measured by the caliper tool.

\section{Determining direction of the horizontal stresses}

Determining the direction of the main stresses is the first step to analyze the geomechanical model. Identifying the 


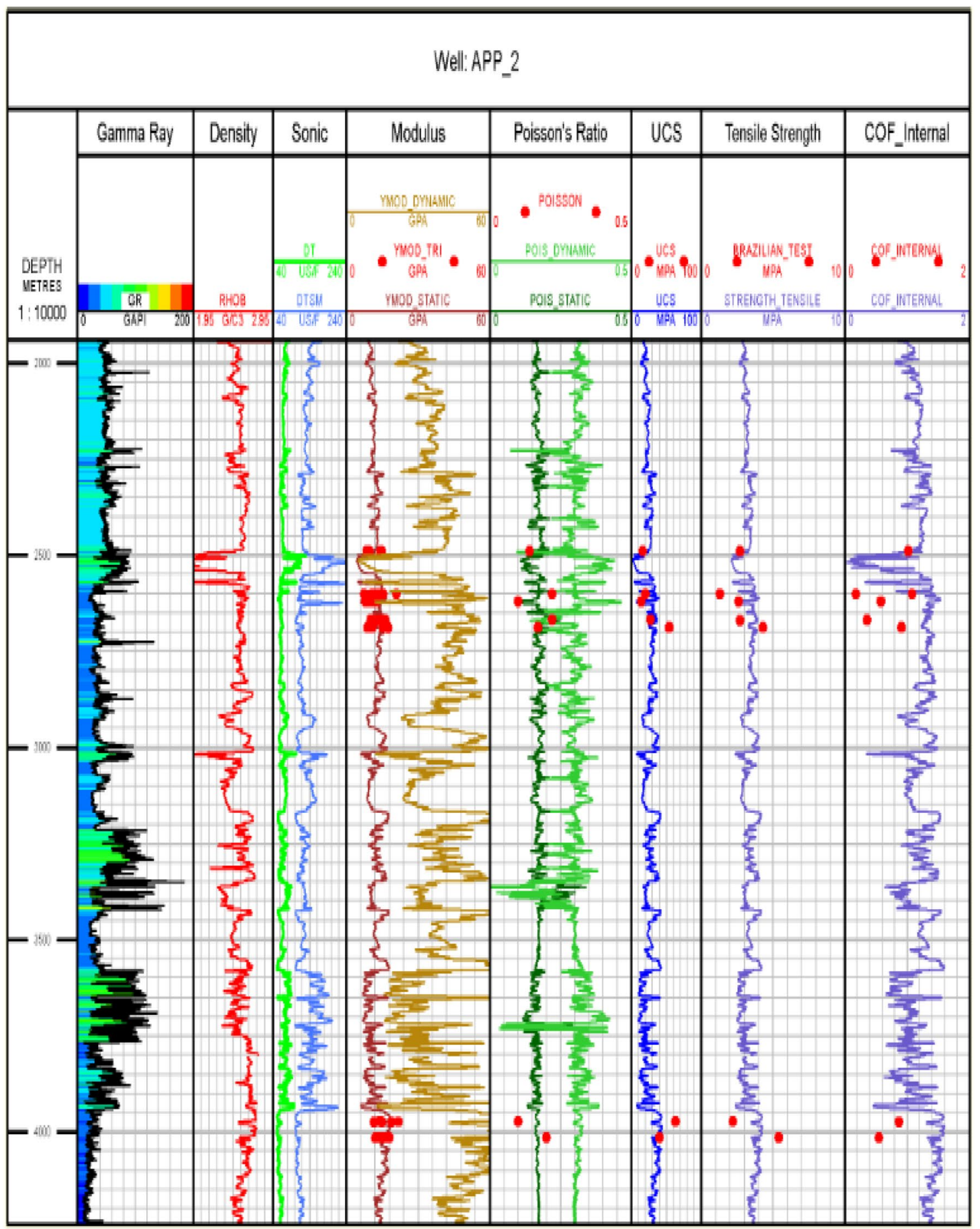

Fig. 5 Elastic parameters of the rock in the well

main stresses leads to designing the correct direction to drill the well with greater stability. Also, their direction design helps to improve perforation operation or complete the well and production planning.
There are various methods, such as breakout orientation, hydraulic fracturing, shear sonic anisotropy, and three-component vertical seismic profile (VSP), to determine the direction of the main stresses in an area. Breakouts are generally 


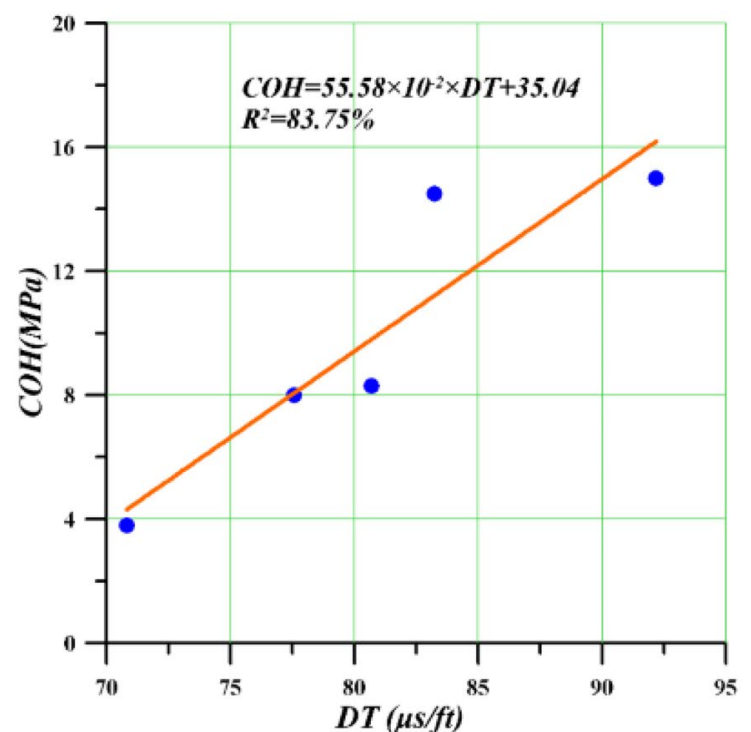

(a)

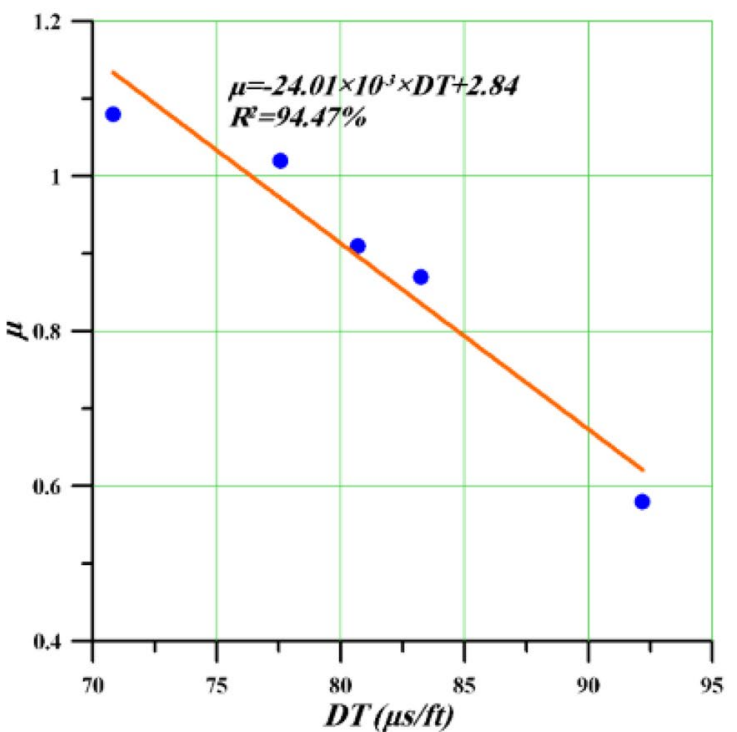

(b)

Fig. 6 a Correlation between rocks' cohesion and DT, b correlation between rocks' friction coefficient and DT

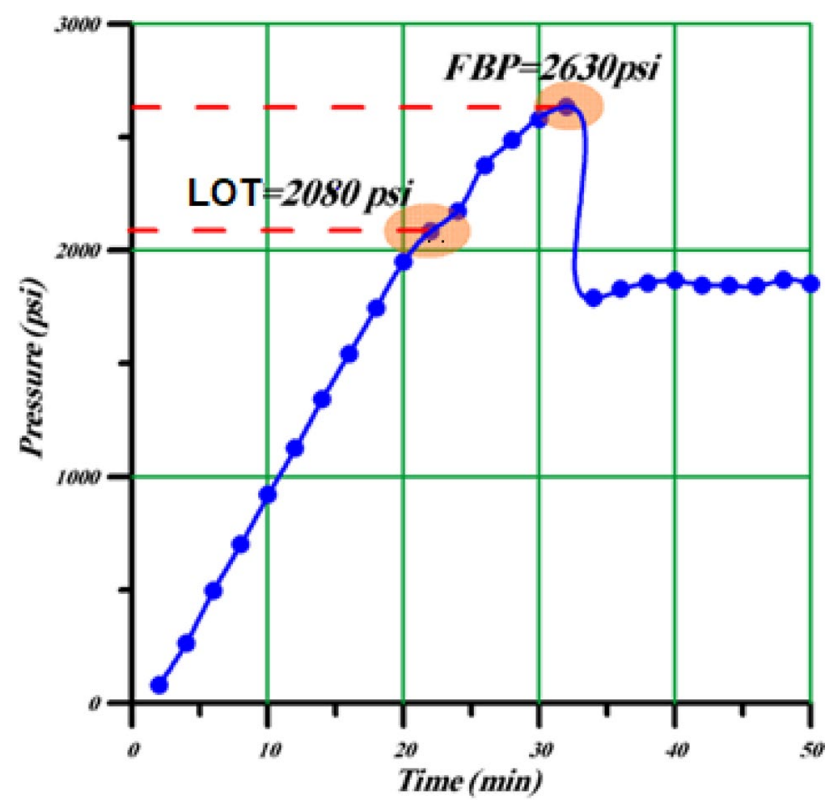

Fig. 7 Results of LOT of the well at a depth of $2205 \mathrm{~m}$ (pressures are inside the well)

Table 3 Input parameters for calculating the maximum horizontal stress at a depth of $2205 \mathrm{~m}$

\begin{tabular}{llll}
\hline$\sigma_{h}(\mathrm{MPA})$ & $\Sigma_{t}(\mathrm{MPA})$ & FBP $(\mathrm{MPA})$ & $P_{p}(\mathrm{MPA})$ \\
\hline 40.66 & 3.22 & 44.46 & 23.55 \\
\hline
\end{tabular}

formed along the direction of the main stress, at least around the opening of the well where the stress concentration is at the greatest level. Thus, in a vertical well, the created breakout orientation determines the direction of the minimum main stress around the well (Fig. 9).

The created breakout orientation around the well can be determined using image logs or by analyzing the oriented multi-arm caliper data.

In a hydraulic fracturing operation, the main fracture usually occurs along the direction of the maximum main stress where the hoop stress is in a tensile state. Therefore, hydraulic fracturing in a vertical well indicates the direction of the maximum main stress. The direction of the induced fracture due to drilling, which is in the direction of the mentioned fractures, can be identified by interpreting the image logs' data. In this study, well graph data were used to determine breakout orientation. In this well, breakouts were observed in almost all dense or low-porosity parts of the Fahliyan Formation, especially in the interlayer areas. Figure 10 shows the breakout observed in the interval of a well from the lower Gurpi to the Sarvak Formation.

Analysis of the data obtained from the orthogonal caliper diagram and their azimuth identified a large number of breakouts with a predominant northwest-southeast direction (NW-SE) (Fig. 11), indicating that the minimum main stress direction $\left(\sigma_{h}\right)$ around the well is approximately NW-SE; therefore, the maximum main stress direction $\left(\sigma_{H}\right)$ is NE-SW. 
Fig. 8 Stress profile in the well $\left(\sigma_{H}\right.$ value is estimated based on LOT data and hydraulic failure theory relations)

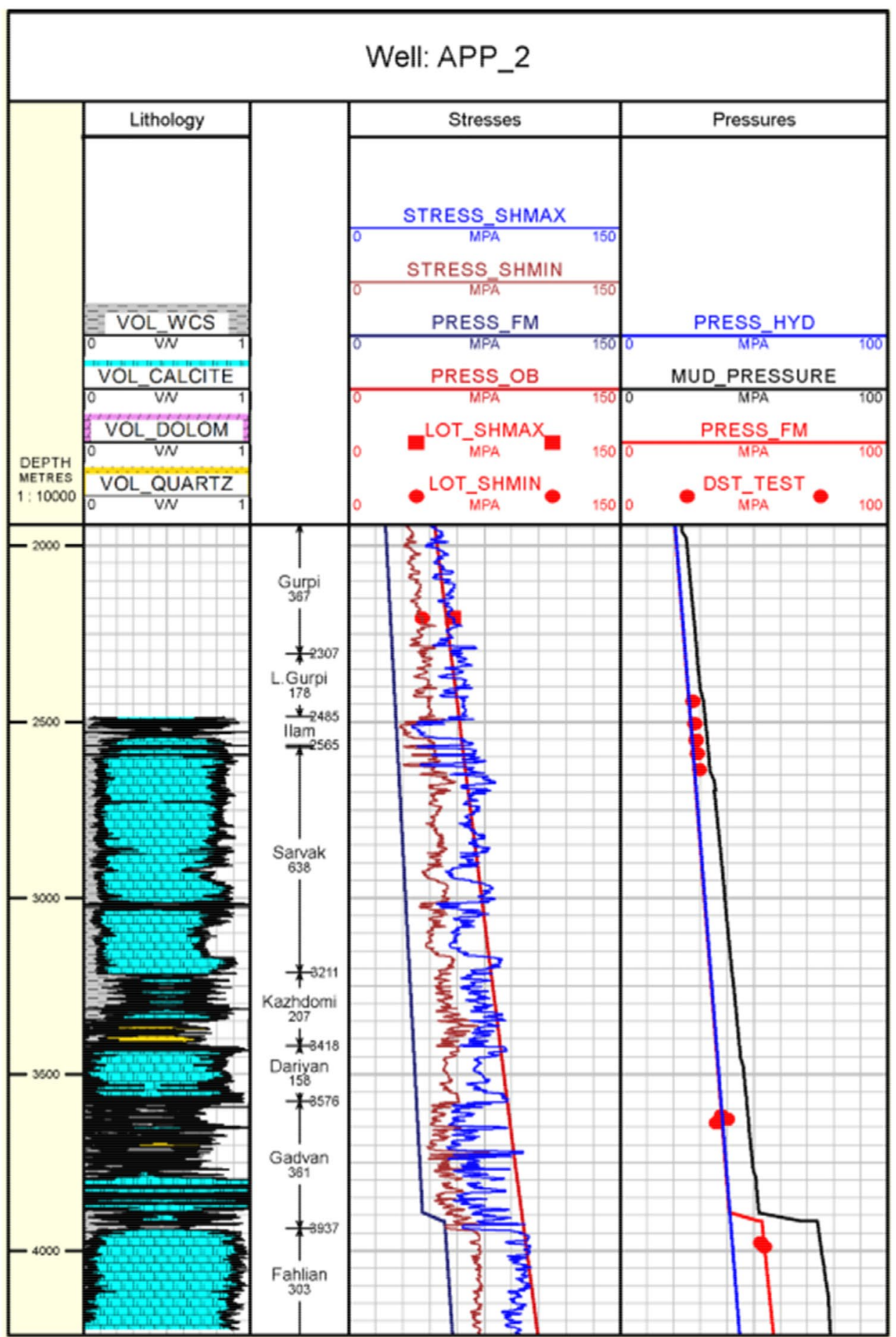

\section{Wellbore stability analysis}

The geomechanical model and well path are used to calculate the concentration of the stresses around the well; further, by comparing them with the rupture criteria in the rock, it can be concluded whether the desired part of the wellbore is stable or not. Rock fractures causing wellbore instability are divided into two general categories: shear and tensile.
The former usually occurs due to low mud weight, while the latter is caused by high mud weight. There are various criteria to predict rock fracture and well stability, of which the Mohr-Coulomb failure criterion is the most common. This criterion is widely used to determine shear failure, and the maximum tensile stress criterion is used to determine tensile failure. 


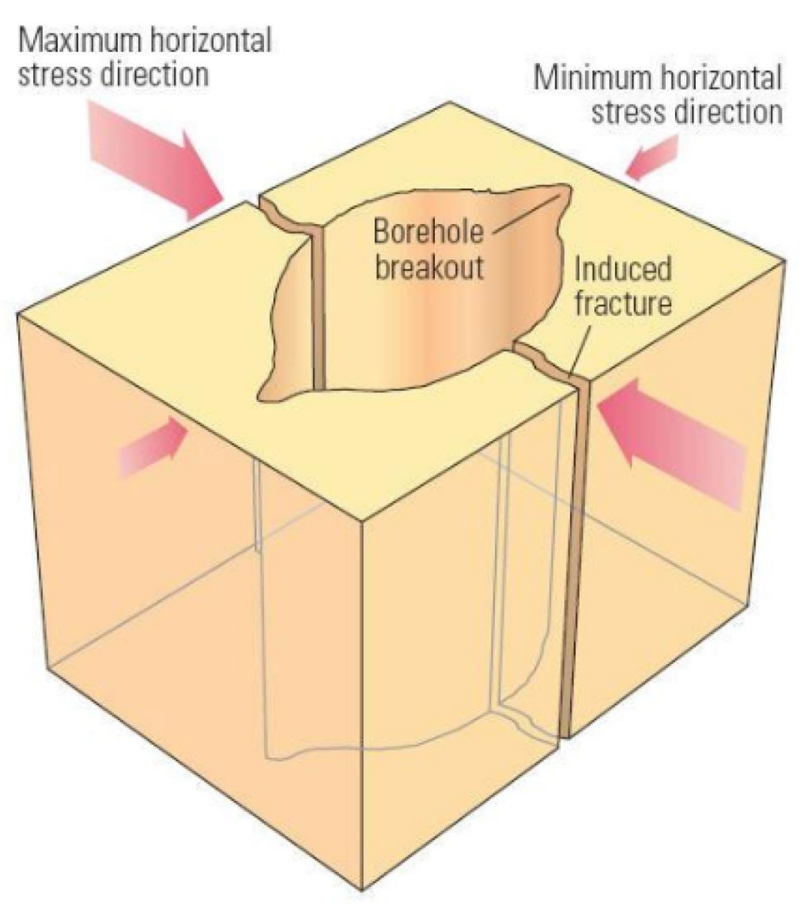

Fig. 9 Relationship of the main stresses with breakout and tensile fractures

Flow pressure, loss, breakout, and tensile fractures are shown in Fig. 12. Depending on the type of pressure, movement of the black line in the pressure column toward each of the colored areas indicates the risk of developing flow, loss, breakout, or tensile fractures.

Since a very high mud weight has been used while drilling the Fahliyan Formation, it is the most problematic formation in the drilling according to the mud window introduced in this well.

The key findings related to stability analysis and the events occurring during drilling in the APP2 well are as follows:

In the 12.25-inch well, the model predicted several breakouts for depths of 2500-2570 (Ilam Formation), 3080-3109 (Sarvak), and 3580-3760 (Gadvan); also, the data from the caliper tool showed several openings at these points (Fig. 12).

At depths of 3415-3450 m, no problem was reported with the well instability, and the model did not predict any failure at these depths. The openings observed in the well were related to the suction created during the pipe-raising operation.

In the 12.25-inch well, mud pressure was very close to drilling mud pressure, at least to prevent breakout and surge; also, swabbing phenomena should be avoided during the well path.

In the 8.375-inch well, the caliper tool showed several breakouts at depths of 3830-3880 m (above Fahliyan
Formation), and the model also predicted shear failures for these depths.

No problem was reported at a depth of $3950 \mathrm{~m}$ during drilling, and the model did not predict any specific failure at this depth. Also, the data obtained from the caliper tool showed appropriate well conditions at this depth (Fig. 12).

In the 8.375-inch well, the weight of drilling mud was greater than that needed to prevent loss; therefore, it is recommended to reduce the weight of the mud in this hole. Although traveling in the well should be done with caution; also, surge and swabbing phenomena should be avoided.

\section{Sensitivity analysis in the surrounding wells}

In this section, a sensitivity analysis is presented regarding the effect of borehole orientation and azimuth drilling on the mud window. This analysis can include both a specific point and a depth interval. Output is derived from the results of the Mechanical Earth Model (MEM), especially the rocks' strength and stress data. With the explanations provided, sensitivity analysis was performed at depths of 2850-3700 m with different angles and azimuths. Figures 13 and 14 show the minimum and maximum mud weights required for safe drilling.

Also, the minimum mud weight required to prevent breakout and the maximum allowable mud weight in order to avoid hydraulic fracture in the formation are both shown. The center of the stereonet represents a vertical well, and the angle of the well increases as it moves toward the circle's boundary. As shown in Figs. 13 and 14, at a depth of $2850 \mathrm{~m}$, drilling in a vertical well or a directional well (with a dip angle of fewer than 50 degrees) to the maximum horizontal stress direction and, at a depth of $3700 \mathrm{~m}$, drilling a directional well in a direction parallel to the maximum horizontal stress (azimuth of 45 degrees) are the worst options.

While drilling in the direction parallel to the main stress is minimal, it is considered the most stable drilling mode. According to Figs. 13a and 14a, drilling in a relatively horizontal position with a low angle to the minimum horizontal stress is the most stable position for a depth of $2850 \mathrm{~m}$. While at a depth of $3700 \mathrm{~m}$, drilling vertically (up to 15 degrees) with a low angle to least horizontal stress (135 degrees) has the slightest instability problem. According to stereonet, at a depth of $2850 \mathrm{~m}$, the minimum weight of breakout mode decreases by increasing the well angle.

This means that for this drilling depth, a horizontal well along the direction of the minimum stress is more stable than a vertical well, or a horizontal well drilled along the direction of main stress is more stable. At a depth of $3700 \mathrm{~m}$, the situation is the opposite; this means that the mud weight required for the occurrence of breakout increases by increasing the well angle. Therefore, at this depth (in Gadvan and Fahliyan Formations),

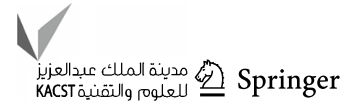


Fig. 10 Breakout orientation in the well

Fig. 11 a Rose diagram of breakout orientation, b breakout orientation in the wells' top schematic
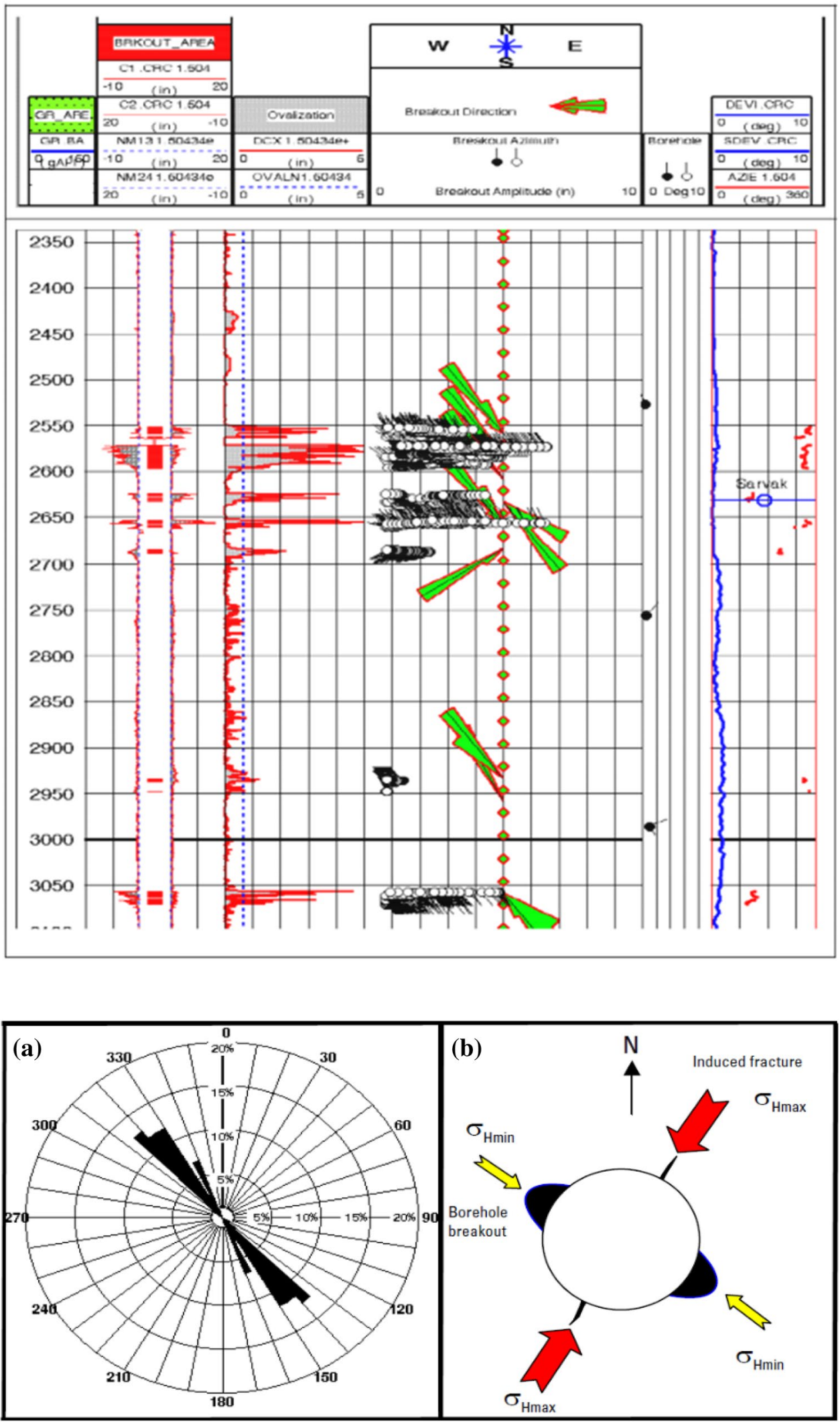


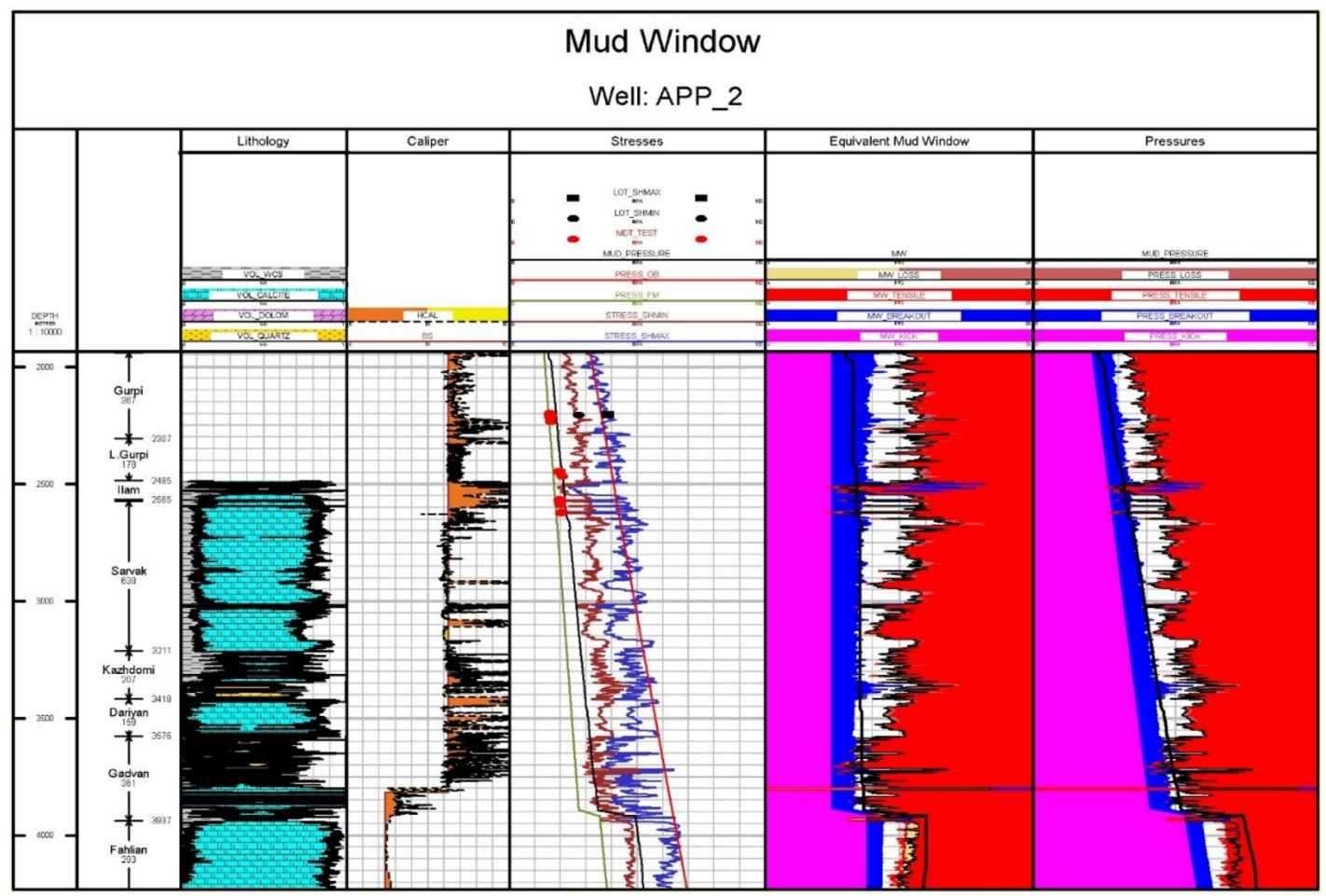

Fig. 12 Analysis of mud window and APP2 well stability

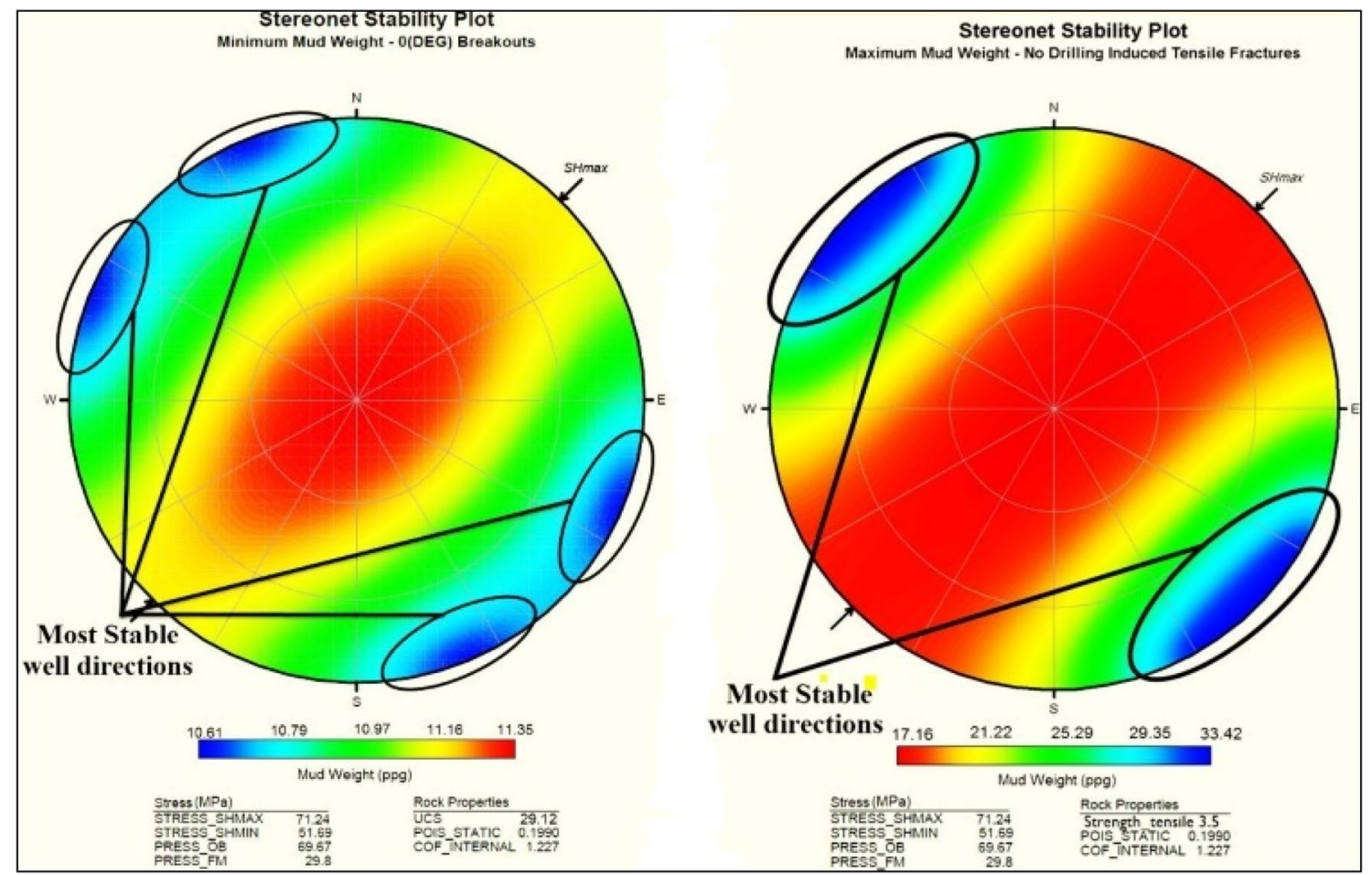

Fig. 13 Stereonet plot of sensitivity analysis of the well stability at a depth of $2850 \mathrm{~m}$ : a minimum required mud weight (left), b maximum allowable mud weight (right) 


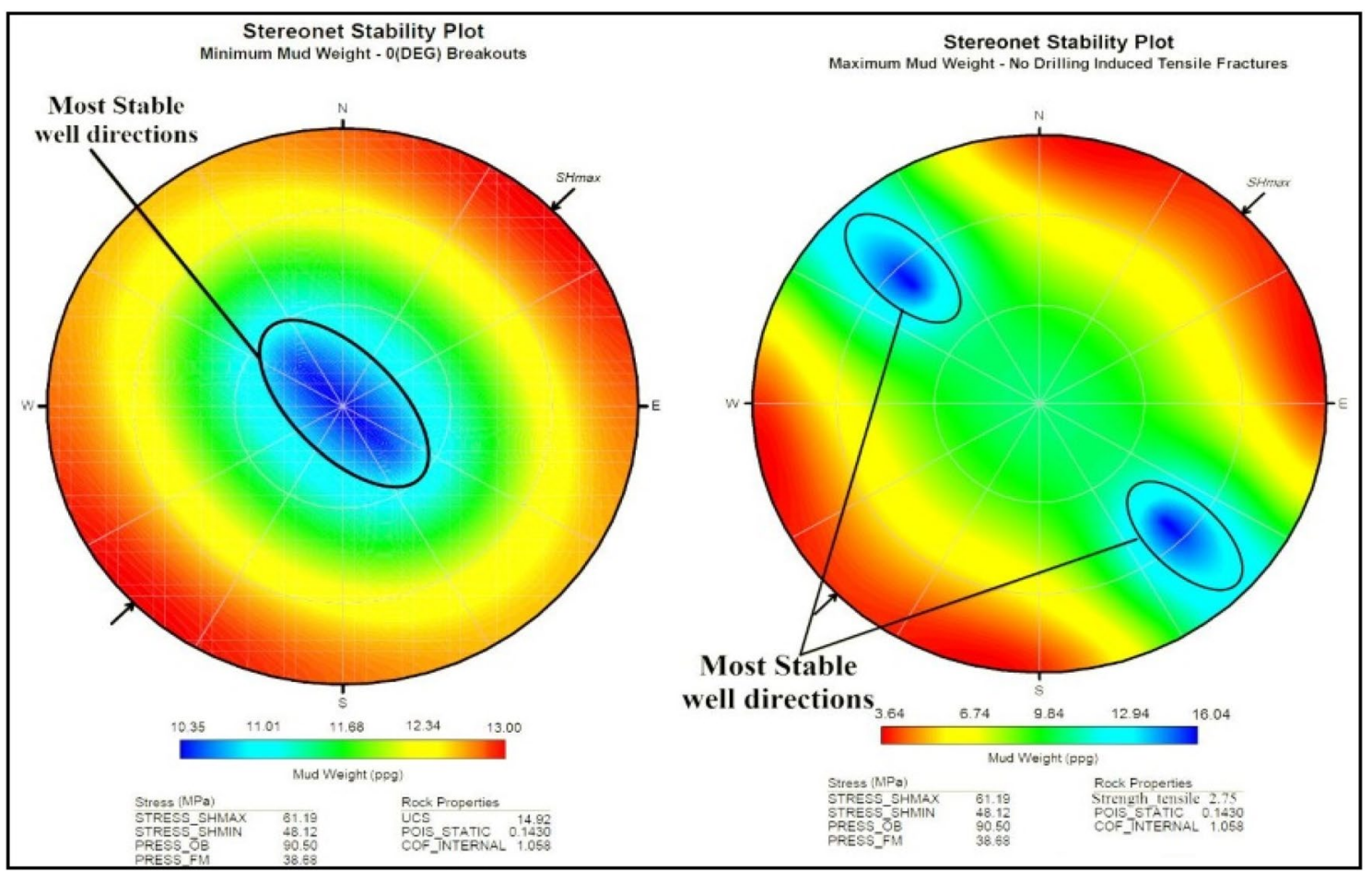

Fig. 14 Stereonet plot of sensitivity analysis of the well stability at a depth of $3700 \mathrm{~m}$ : a minimum required mud weight (left), b maximum allowable mud weight (right)

drilling a vertical well or a well with a low angle is more stable than drilling a horizontal well.

Figures $13 \mathrm{~b}$ and $14 \mathrm{~b}$ show the maximum mud weight allowed for preventing tensile cracks in the formation. The results in this section are the same as those presented in Fig. 13a. At this depth, digging a horizontal well along the main stress direction is at least more stable. Also, at a depth of $3700 \mathrm{~m}$, a relatively horizontal well (with a dip angle of about 60 degrees) is at least more stable along the main stress direction.

As the stress regime in the well is changed from normal to strike-slip length, stable drilling directions are also changed. Further, the mud window obtained at a depth of $3700 \mathrm{~m}$ (ppg16.04-10.35) is narrower than that at a depth of $2850 \mathrm{~m}$ (ppg33.42-10.61).

\section{Conclusion}

In this research, a geomechanical model (MEM) was constructed for the APP2 well. Also, the existing data were used in the best possible way, being confirmed by laboratory results. Some problems reported while drilling with the mud window built into the geomechanical model confirmed the accuracy of the analysis. The following results were obtained from the stability analysis of the APP2 well:
- Based on the geomechanical model (MEM), breakouts were identified at the depths of 2500-2570 m (Ilam), 3080-3109 m (Sarvak), and 3580-3760 m (Gadvan). At the depths of 3415-3450 m, no problem was reported with the well instability, and the model did not predict any failure. The openings observed in the well were related to suction, as well as surging and swabbing phenomena that occurred during pipe-raising and lowering operations.

- The MEM was calculated with the help of the available data for the reservoir area in this field, and relationships were presented for mechanical properties of source rock (Fahliyan Formation) in the area.

- At the depths of 3830-3880 m (upper Fahliyan), several breakouts occurred. In the 8.375-inch well, drilling mud weight was more than that needed for preventing wastage; thus, it is recommended to reduce the mud weight in the well. Also, traveling in the well should be done with caution, and pinching should be avoided.

- Based on calculations of the minimum mud weight required for a depth of $2850 \mathrm{~m}$, the most stable possible drilling position was an almost horizontal well in the direction closest to the minimum main stress. Also, for a depth of $3700 \mathrm{~m}$, drilling in the azimuth of about 135 degrees with an angle of about 15 degrees was the most stable drilling position. It should be noted that the 
optimal direction and angle of the well may be different due to changes in the stress regime in different layers. According to the calculations related to the maximum allowable weight for the well at a depth of $2850 \mathrm{~m}$, horizontal drilling along the main stress direction was the least stable state possible. For a depth of $3700 \mathrm{~m}$, digging a well with an angle of about 60 degrees along the main stress direction was at least more stable.

Open Access This article is licensed under a Creative Commons Attribution 4.0 International License, which permits use, sharing, adaptation, distribution and reproduction in any medium or format, as long as you give appropriate credit to the original author(s) and the source, provide a link to the Creative Commons licence, and indicate if changes were made. The images or other third party material in this article are included in the article's Creative Commons licence, unless indicated otherwise in a credit line to the material. If material is not included in the article's Creative Commons licence and your intended use is not permitted by statutory regulation or exceeds the permitted use, you will need to obtain permission directly from the copyright holder. To view a copy of this licence, visit http://creativecommons.org/licenses/by/4.0/.

\section{References}

Abdollahipour A (2015) Crack propagation mechanism in hydraulic fracturing procedure in oil reservoirs. University of Yazd, Iran

Al-Ajmi A (2006) Wellbore stability analysis based on a new truetriaxial failure criterion. KTH

Ameen MS, Smart BG, Somerville JM, Hammilton S, Naji NA (2009) Predicting rock mechanical properties of carbonates from wireline logs (a case study: Arab-D reservoir, Ghawar field, Saudi Arabia). Mar Pet Geol 26(4):430-444

Amiri M, Lashkaripour GR, Ghabezloo S, Hafezi Moghaddas N, Heidari Tajareh M (2018) 3D spatial model of Biot's effective stress coefficient using well $\log$ s, laboratory experiments and geostatistical method in the Gachsaran oil field, south-west of Iran. Bull Eng Geol Environ 78(6):4633-4646

Amiri M, Lashkaripour GR, Ghabezloo S, Moghaddas NH, Tajareh MH (2019) Mechanical earth modeling and fault reactivation analysis for $\mathrm{CO}_{2}$-enhanced oil recovery in Gachsaran oil field, south-west of Iran. Environ Earth Sci 78(4):112

Fjar E (2008) Petroleum related rock mechanics, vol 53. Elsevier

Gao Q (2019) Initiation pressure and corresponding initiation mode of drilling induced fracture in pressure depleted reservoir. J Energy Resour Technol 141(1):012901

Gholami R, Moradzadeh A, Rasouli V, Hanachi J (2014) Practical application of failure criteria in determining safe mud weight windows in drilling operations. J Rock Mech Geotech Eng 6(1):13-25

Kanfar MF, Chen Z, Rahman S (2017) Analyzing wellbore stability in chemically-active anisotropic formations under thermal, hydraulic, mechanical and chemical loadings. J Nat Gas Sci Eng 41:93-111

Kidambi T, Kumar GS (2016) Mechanical Earth Modeling for a vertical well drilled in a naturally fractured tight carbonate gas reservoir in the Persian Gulf. J Pet Sci Eng 141:38-51. https:// doi.org/10.1016/j.petrol.2016.01.003

Lund B, Zoback M (1999) Orientation and magnitude of in situ stress to $6.5 \mathrm{~km}$ depth in the Baltic Shield. Int J Rock Mech Mining Sci 36(2):169-190

Ma T, Chen P, Yang C, Zhao J (2015) Wellbore stability analysis and well path optimization based on the breakout width model and Mogi-Coulomb criterion. J Pet Sci Eng 135:678-701

Maleki S (2014) Comparison of different failure criteria in prediction of safe mud weigh window in drilling practice. Earth Sci Rev 136:36-58

Mirzaghorbanali A, Afshar M (2011) A mud weight window investigation based on the Mogi-Coulomb failure criterion and elastoplastic constitutive model. Pet Sci Technol 29(2):121-131

Moos D (2003) Comprehensive wellbore stability analysis utilizing quantitative risk assessment. J Pet Sci Eng 38(3-4):97-109

Rajabi M, Bohloli B, Ahangar EG (2010) Intelligent approaches for prediction of compressional, shear and Stoneley wave velocities from conventional well log data: a case study from the Sarvak carbonate reservoir in the Abadan Plain (Southwestern Iran). Comput Geosci 36(5):647-664

Rutqvist J, Moridis GJ, Grover T, Collett T (2009) Geomechanical response of permafrost-associated hydrate deposits to depressurization-induced gas production. J Pet Sci Eng 67(1-2):1-12

Shen X, Xi G, Wai C, Clemmons DR (2015) The coordinate cellular response to insulin-like growth factor-I (IGF-I) and insulin-like growth factor binding protein-2 (IGFBP-2) is regulated through vimentin binding to receptor tyrosine phosphatase $\beta$ (RPTP $\beta)$. J Biol Chem 290(18):11578-11590

Younessi A, Rasouli V (2010) A fracture sliding potential index for wellbore stability analysis. Int J Rock Mech Min Sci 47(6):927-939

Zeynali ME (2012) Mechanical and physico-chemical aspects of wellbore stability during drilling operations. J Petrol Sci Eng $82: 120-124$

Zhang K, Zhang LL, Zhao XS, Wu J (2010) Graphene/polyaniline nanofiber composites as supercapacitor electrodes. Chem Mater 22(4):1392-1401

Zoback M (2003) Determination of stress orientation and magnitude in deep wells. Int J Rock Mech Min Sci 40(7-8):1049-1076

Zoback MD (2010) Reservoir geomechanics. Cambridge University Press, Cambridge

Publisher's Note Springer Nature remains neutral with regard to jurisdictional claims in published maps and institutional affiliations. 